\title{
sciendo
}

\section{The role of Supply Chain in improving competitiveness}

\author{
Amine GHOUMRASSI \\ Bucharest Academy of Economic Studies, Bucharest, Romania \\ Ghoumrassi.Amine@Hotmail.Fr \\ Habib KABALAN \\ Bucharest Academy of Economic Studies, Bucharest, Romania \\ Habib.Kabalan@Gmail.Com \\ Gabriela TुIGU \\ Bucharest Academy of Economic Studies, Bucharest, Romania \\ Gabriela.Tigu@Ase.Ro
}

\begin{abstract}
The international economic environment is witnessing a series of radical transformations, particularly in the marketing field. The liberalization of markets and the international marketplace integration have led to qualitative developments of the economic entities at various levels especially from the technological point of view. These transformations have affected most of the modern world, and Algeria is no exception to that phenomenon. Its economy is witnessing several modifications in order to move towards a modern market economy compliant with the current definition of freedom of exchange. This is the goal that Algeria seeks to reach by adhering to the World Trade Organization, whose rules are based on concept of free market, lawful competition as well as the lifting of major customs barriers. Companies have to exploit all the possibilities and strategies to improve their productivity, management and overall workflow in order to rise above the challenge and succeed in establishing themselves strongly in such a market. In this instance, the supply chain becomes the main symbol of the link between production sites and consumption locations thus making supply chain management one of the most progressive forms of dynamic and integrated management and is considered a main driver of competitive. In this paper, we attempt to prove the importance of the aforementioned concept of supply chain management under the form of a case study that assess the competitiveness of the AURAS mills in Algeria to determine the various elements that are the main contributors to the improvement of the overall position of the company on the market as well as the drivers behind the continuous progress and innovation in management of the dynamic components of the company. We expect to prove that a shift in the structure of the company towards the creation of an autonomous supply chain department will improve the competitiveness of AURAS mills as well as provide a clear development and amelioration path for the overall functioning of the company.
\end{abstract}

Keyword: Supply Chain, Management, improving competitiveness, Economy, Global Market, Logistics

\section{Introduction}

The word logistics became famous and well known from late 19th century, "from the French word "Logistique" That was first used by Baron Henri De Jomini, who was a general in the napoleon's army in 1838."(Schileru, 2008).

The word logistics can also "be traced back to ancient war times of Greek and Roman empires when military officers titled as 'Logistikas' were assigned the duties of providing services related to supply and distribution of resources". (Posea, C., 2005)

This was done to help the soldiers to move from their position to a new forward position in an efficient way, without missing necessary resources which is an essential issue that affects the result of the conflict.

This also means, thinking how to affect the enemy supply chain, meanwhile maintaining its own supply chain and even performing it. 
Digging deep into the research and the origin of this word, it appears that the word Logistics appeared for the first time in English in 1810 in a book named "The Elements of Art of War" By Dr. William Muller; Dr. Muller was an instructor at the University of Gottingen. Before the official launch of the book, Dr. Muller changed his mind and renamed his book to "The Elements of the Science of War", and that was in 1811. As stated in "Essentials of Logistics and Supply Chain Management":

During the Second World War (1939-1945), logistics evolved greatly. The army logistics of [the] United States and counterparts proved to be more than the German army could handle. [...] The United States military ensured that the services and supplies were provided at the right time and at the right place. It also tried to provide these services when and wherever required, in the most optimal and economical manner. The best available options to do the task were developed. This also gave birth to several military logistics techniques which are still in use, albeit in a more advanced form. (Haniefuddin and Khadar Baba, 2013)

Since then logistics has been developed to be also used in businesses and organizations. However logistics cannot be determined as a science, since it doesn't follow fixed definitions and tables but rather is a developed tool to ensure that the requested criteria have been met. And also helps generating new indicators that show the supply chain weaknesses.

Our main focus in this paper will be to assess AURAS mills' logistic aspect and determine the areas of potential improvement to then provide the company with a possible action plan to implement. We will use the following as a guide in our research: Does AURAS mills function in optimal conditions from the logistic point of view? What are the potential improvements that could be implemented? What will be the effect of such changes?

\section{Literature review \\ Definition of logistics:}

In order to better understand the evolution of the logistics, the most common and known definitions were retained:

Logistics, according to $\mathrm{Ph}$. Kotler (1995) ${ }^{1}$ includes:" planning, implementation and control of the physical flows of materials and finished products from their points of origin to the points of use so as to generate profit and meet customer requirements (logistics source of competitiveness)."

Logistics implies According to The US professional Logistics Management Board, "a process of planning, implementing and controlling the flow, efficient and effective storage of goods, services and related information." (Balan, 2004.) 2 One of the most prestigious logistics groups in the US, The Council of Logistics Management, uses the "logistic management" term, which is defined as: "the process of planning, implementing and controlling the bi-directional and efficient flow of goods and services and related information between a point of origin and a point of consumption, the cusp of satisfying consumers' demands "(Lambert and Stock, 1993)

In 1962, the National Council of Physical Distribution Management (NCPDM) defined logistics with the activities that logistics staff needs to carry out as follows: "The

\footnotetext{
${ }^{1}$ Kotler, P. (1995). Dirección De Marketing. 8aㅡ ed. Prentice Hall.

2 Balan, C. (2004) Logistica, funcţie integratoare şi de competitivitate Editia a II, Editura Uranus Bucuresti, pag.26-27
} 
industry and commerce employee involved in the vast array of activities required achieving an efficient movement of products, from leaving the manufacturing process to reaching the consumer. It also includes the movement of raw materials from suppliers to manufacturers. These activities include: freight transport, warehousing, cargo handling, packaging, stock control, plant and warehouse selection, order handling, market forecasting and customer service." (Enciu 2007).

Logistics is "the art of having the necessary resources at the desired time and

PICBE | 591 place" (Posea, 2005), in other words, logistics deal with the complex responsibilities of the movement of raw materials, semi-finished products and finished products and the elaboration of an optimal itinerary cost.

The European Logistics Association presents the following definition for logistics: "Organization, planning, control and deployment of flow of goods from conception, supply to production and distribution to the consumer in order to meet market requirements at a minimum cost" The Institute of Logistics (IL), founded in 1993 by the merger of the Institute of Materials Management, defines logistics in two ways: "logistics is how to position resources in time" and "logistics is the strategic management of a logistic chain." According to the IL, the "logistics chain" is a sequence of events to meet customer needs at the highest quality level. This sequence may include supply, production, and distribution, waste management, associated with transport, storage and IT. Logistics is therefore the strategic management of supply, production, distribution, transportation, storage, recycling and IT activities.

In 2005, the following definition of logistics was given: "Deliver a product in good condition at the right time, in the right place, in the correct and necessary quantity, in the appropriate packaging, preceded, accompanied and followed by accurate information on legal documents, everything in the best economic conditions" (Enciu 2007). This definition focuses on accompanying documents, confirming and tracking the flow of information, and ensuring that the history is established, representing objective evidence for traceability.

As stated by Gleissner and Femerling (2014): "The European Committee for Standardization CEN (Comite' Europeen Normalisation) defines logistics as the planning, execution and control of the movement and placement of people and/or goods and of the supporting activities related to such movement and placement, within an system organized to achieve specific objectives."

\section{Importance of logistics}

One of the main reasons that logistics has been receiving an increasing attention is linked to the noticeable rise of the logistics cost. Management then realized that the way to ensure the competitive advantage and profitability began with the amelioration of customer service and cost reduction. The importance of the logistics lies in the following:

High cost considerations: The statistics show that $80 \%$ of the national wealth in the United States of America continues with logistics activities, and that these activities employ about $60 \%$ of the labor force there, among which is the transport activity.

Length of supply and distribution lines: The thrive towards globalization in industry as well as the interest in exceeding the local market share into a large non-local portion is mainly relying on logistics, this lead into the increasing importance on the supply chain from the multinationals and big companies that aims to be an influential part of the international market.

Logistic is important for strategies: Companies are taking a long time to implement means for distinguishing their brand name from that of their competitors, especially that 
production expenses are heavily linked to the proper performance of logistics business in terms of cost and customer service. A company that has succeeded in making the distinction in the logistics service is able to build a preferential advantage compared to its competitors, and helps the organization to expand the market and increase the market share and profitability of the enterprise.

\section{Objectives of logistic}

Under the logistics management project, each company must "achieve at least six different operational objectives. These operational objectives, which are the main determinants of logistics performance, include rapid response, minimum variance, minimum inventory, transportation, quality and lifecycle support." (V skills certified, 2018)

Rapid Response: It deals with the ability to meet customer requirements in a timely manner. The continuous advancement in technology and the integration of information management techniques has increased the ability to delay logistics tasks until the later stages of the overall process, and then quickly delivered the required inventory.

Minimum variance: Variations is unexpected events that limit logistic performance. Delays in delivery or delay of order processing can lead to a logistic indicator failure. An unexpected break in the manufacturing process, goods that arrive damaged at the location of a customer or delivery to an incorrect location - all lead to an interruption of time in the operations to be solved. The traditional solution for adapting variance was to establish a certain level of safety stocks or to use high-cost premium transport. Given the costs and risks involved, such practices have been replaced by the use of "information technology to achieve positive logistical control. To the extent that variations are minimized, logistic productivity improves as a result of economic operations" (V skills certified, 2018). From which is deduced that the main target of global logistics management is to reduce the levels of variance to a minimum.

Minimum inventory: Refers to the inventory usage rate over time. Active traffic, along with availability of inventory, means that inventory tools are actually used. The goal is to "reduce inventory deployment to the lowest level, consistent with customer service goals, to achieve the lowest total cost of total logistics" (V skills certified, 2018). The objective is to ensure the appropriate availability of items while maintaining the lowest levels of inventory. To achieve this goal, the logistics tasks must match the requirements of the entire business, not just individual business units.

Transport: One of the most important logistic costs is transport. The cost of shipping is directly related to the product type, shipment size and distance. The logistical goal is to reduce these costs by studying the market and the best mode of transport.

Quality Improvement: Companies are looking for continuous improvement of quality. Global Quality Management (TQM) is currently one of the most important factors in all aspects of the industry. The commitment to TQM is probably one the ultimate contributor to the advancement of logistics. If a product becomes defective or the service promise is not preserved, logistics adds little value. Logistics costs, once extended, cannot be downgraded. When the quality level of a product is sub-par, the logistic practice should be halted, reassessed and then re-run. The Logistic process itself must meet rigorous quality standards. If the shipped goods arrive damaged, there is an extra cost for logistics. To avoid additional costs, logistics aims to look for quality from the beginning.

The establishment of the logistics activity objectives is an important activity of the company's management, which, together with other actions, contributes to the achievement of the general objective of the company, the objective for which it was set up. 


\section{Relation between logistics and enterprise activities}

Through the definitions above, we can see the strong relationship between the logistic activity and marketing, it also shows the relation between logistic and production activities with also the financial activities.

This is due to the fact that logistic activities starts from the very beginning with raw material until the last activity which is delivering the final product to the final customer.

Relation between logistic and production activities: The production department takes responsibility for receiving raw material and turning it into a final or semifinal product or service, the production department takes care of the production and the transformation of the raw material into a usable product, the production departments' responsibility is to keep this transformation at the lowest costs possible, and also to deliver these products. Here comes the role of logistics that provide the raw material from the market to the production zone, and also organize the circulation of the raw material until it reaches its final destination at the factory or the production area. We also notice that logistics need to collaborate with the production department to exchange information and know the needs of this department.

Relation between logistic and Marketing: The marketing department is responsible for planning and implementing the content of the product whether it is a commodity or service, pricing it or promoting it and distributing it in order to develop an exchange process with the target groups within the organization's markets. Marketing works to place products in appropriate distribution channels and thus facilitate exchange. Marketing also aims to establish deep and long-term relationships between the organization and its customers. Creating spatial and temporal value.

Marketing needs a supply that allocates the resources available to the organization and changes this allocation according to market changes. It also helps to achieve the points by providing the right product at the right time and at the right cost

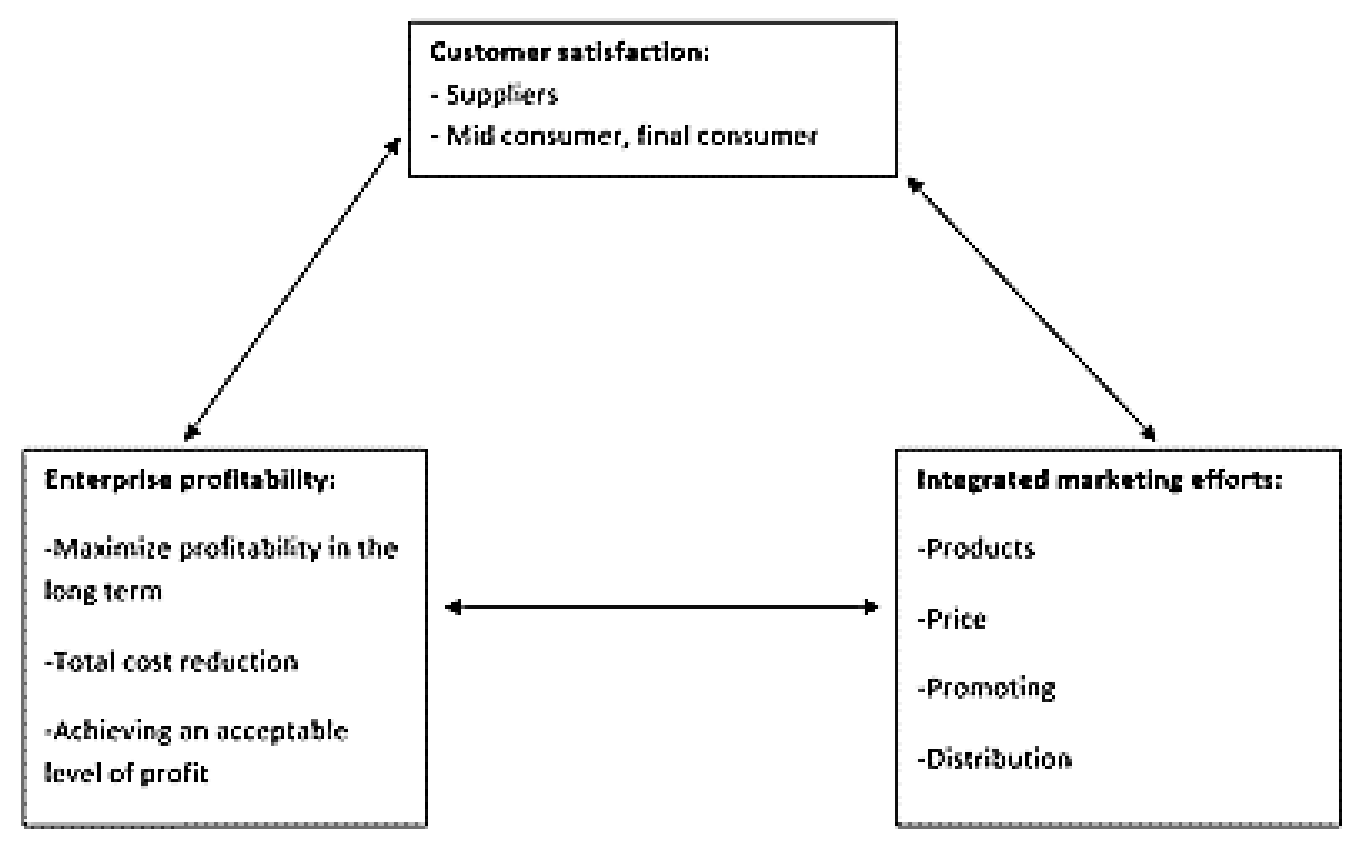

Figure I: Marketing concept from supply perspective Source: Authors' own design. 
Figure I shows that consumer satisfaction is directly related to suppliers and intermediate or final users, and this is only by harmonizing the integrated efforts of marketing through (product, price, promotion, distribution), thus achieving competitive advantage in the market. As for the profitability of the institution, it is necessary to identify the needs needed to reach profitability in the long term.

From a financial perspective, reaching this goal means cutting costs.

To resume what's being said up, the figure bellow shows the common points between each of the logistics and productions and marketing.

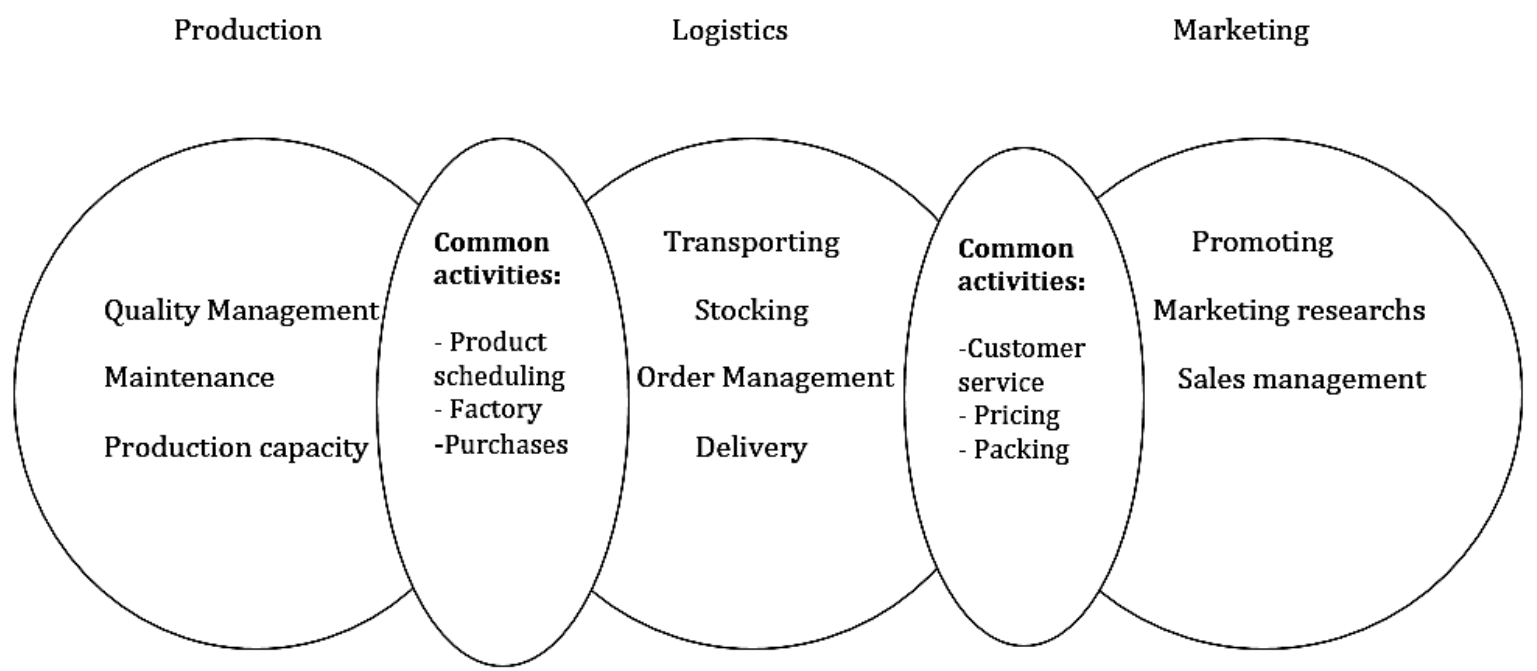

Figure II: Common boundaries between supply, marketing and production Source: Authors' own design.

It is noted from the figure above that the customer service standards can be subject to both production and supply departments and at least coordination between these two departments in relation to this activity. The integration and coordination between the three functions inevitably leads to improving the performance of the organization in terms of cost reduction and customer satisfaction

\section{Competitive through the supply chain (logistics)}

The market development and the technology include permanent risks for companies, since the trade revolution and trade without border, too many companies lost their local and international markets, and too many companies are seeking ways to promote their products in a foreign market taking into consideration defeating local products. Since the logistics is the only way for the product to reach a foreign market taking into consideration several factors and competitiveness key performance.

Since the logistics objective is to reduce cost and make the product reach the right place at the right moment with reduced costs, high quality and good customer satisfaction rating, the logistics is a key for nowadays competiveness.

\section{Methodology}

To go forth with our paper, we opted for a case study of the AURAS Mills in Algeria that will allow us to determine and understand the weaknesses and flaws in the logistic design of the company and thus providing a basis for an improvement action plan. In line with 
that approach we performed a series of meetings with the various employees of the company that guided us through the logistic process in place. In addition to the employees, staff and management testimonies collected we performed a physical inspection of the various departments and units that are involved in the process. The data, information and notes collected were then studied, assessed and subjected to a series of hypothetical scenarios in order to determine the weak links as well as the drawbacks of the system in place. This provided us with a number of points that were apparent to be the cause of the weak competitive advantage of the company as well as the main reasons for the overall decrease in performance of the company.

\section{Case study of AURAS mills: results and discussions Enterprise overview}

Since the independence of Algeria, the agriculture sector has been well taken care of because it meets the needs of citizens. It is the establishment of a company for flour and pastries.

El Auras Mills is one of the oldest production establishments. The company is located in the west of Algeria. The company was established in 1977 and the completion period is 12 years.

The company started its production activity in 1986 with a capital of 5,000,000.00 DA and a number of workers of 160 workers and an estimated production capacity of 2000 quintals/ 24 hours.

The reasons for the establishment of the unit: The main reason is due to political and economic reasons, also in accordance with the scheme of distribution of economic poles to the whole country.

\section{Objectives of the company}

- Meet the needs of the region and the country

- Supply the national market with high quality products

- To provide jobs for the residents of the region

\section{Problems facing the institution}

- Geographic location: The company is located in the middle of the mountains, very hard of access, the roads are dangerous and not fully completed.

- Transportation: the company is facing major issues due to the fact that it only owns 10 trucks for the totality of the transportation activities nationwide. The division of which is shown in table I below.

Table I: characteristics of the trucks owned by AURAS mills

\begin{tabular}{|l|l|l|l|l|}
\hline Truck category & 20 tons & 10 tons & 2.5 tons & Mini truck \\
\hline Quantity & 5 & 2 & 1 & 2 \\
\hline
\end{tabular}

- Weather conditions: The Company is located in the middle of the mountains in an area known for its harsh winter; the roads are very dangerous, especially in snowy conditions, which makes the timely delivery of orders as well as the timely receipt of purchases very difficult during winter.

- Auras Mills is an industrial company, it follows an industrial organizational chart, which divides the company into several departments and each department has its own tasks and duties. 


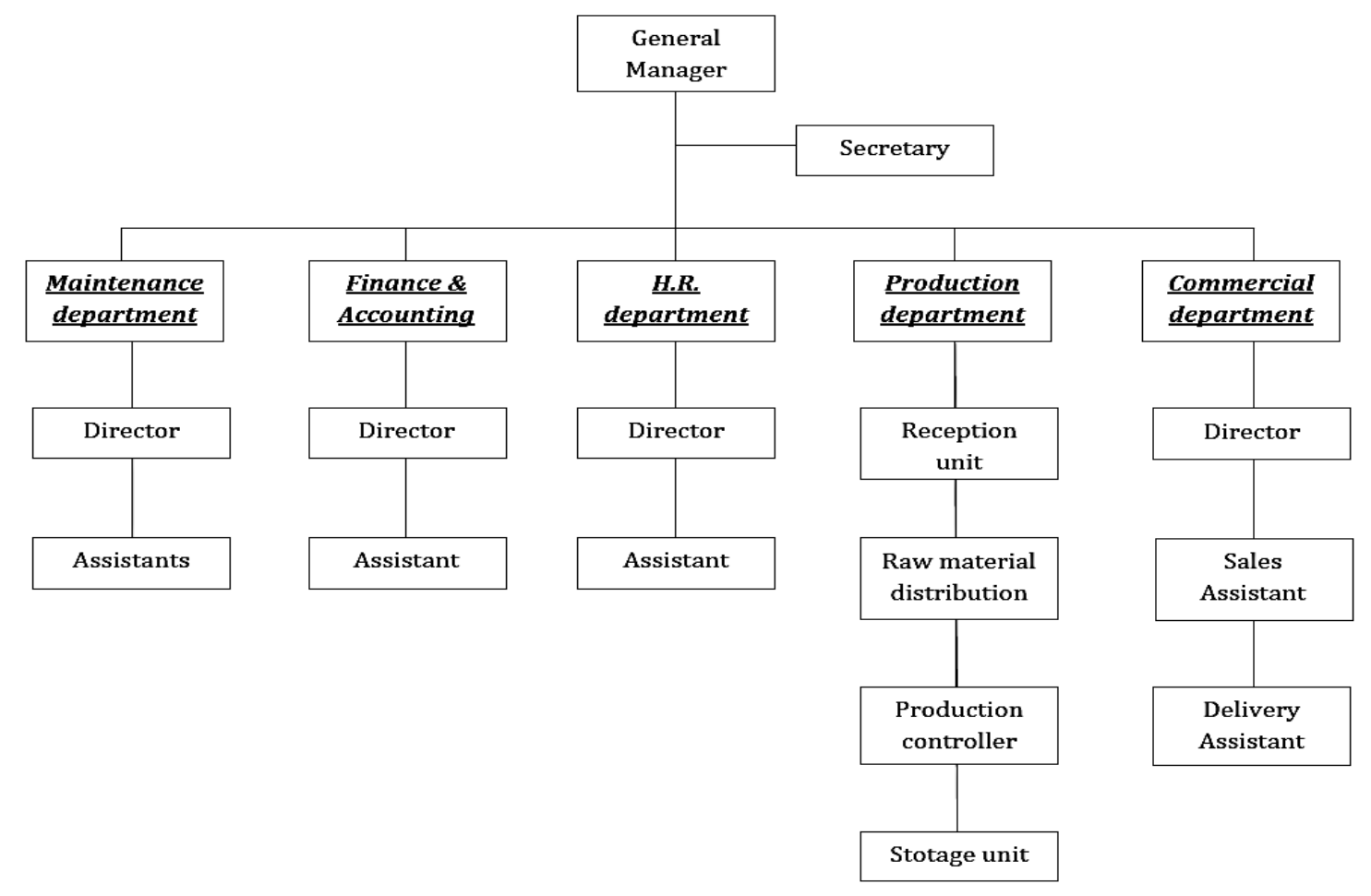

PICBE | 596

Figure III: AURAS mills structural chart

Source: Authors' own design.

From figure III above we can see that the company is managed by a general manager that has a secretary as first and direct assistant, the manager is in charge of the major decisions within the company and insures the correct flow of the information and the proper coordination between the various departments.

Maintenance department: This department is in charge of the overall maintenance of the materials, equipment and facilities within the company. Though it might not appear to be of great importance, it is crucial to the maintaining of the proper workflow as defective equipment or unusable facilities put a halt to the entire production process and lead to loss of money, time as well as increased expenses.

Finance and accounting: the department is managed by a director with the help of an assistant; it is charged with the entire financial aspect of the workflow. The financial department will process invoice payment, cash collection, bill issuing, expenses, client accounts etc. This department is involved in almost every aspect of the process as the approval for any action that involves money transfer (into or out of the company) is the strictly confined within this department.

Human Resources: This department is managed by a single director with the help of an assistant; it is tasked with handling the human capital of the company: recruitment, salaries, bonuses, providing accommodation and transportation for employees on site, insurance etc.

Production department: In general this is the department in charge of transforming raw material into a final product, while maintaining an adequate quality level and a reasonable cost. The production department is divided into several units, starting with the unit responsible for the receiving of the raw material, moving to the unit in charge of organizing the distribution of the received material into the allocated production facility to be processed. The $3^{\text {rd }}$ unit controls the quality of the production 
process as well as the end product and insures the matching of the customer requirements and the market standards, the $4^{\text {th }}$ and last unit is responsible for the storage of the finished products under the appropriate conditions awaiting distribution to the customers.

As for the commercial department, it mainly follows the division found in the first 3 departments, namely a director that is in charge of the main process, aided by a sales assistant. These two are responsible for the actual sales process of the products and are the main contact point with the client. They are aided in the physical delivery of the requests and orders to the customers by a delivery assistant.

\section{Supply and competitive strategy of the enterprise}

Diagnosis of the reality of supply activities and supply chain in the enterprise.

The enterprise has a variety of basic activities and support activities that fall under the umbrella of supply chain tasks, but the degree of interest and focus is different for each individual activity. Below is a description of each tasks and the interest given to it by management:

1- Customer services: the enterprise gives priority to the customers and customer services; taking into consideration that flour is a popular product and constitutes an essential portion of the consumer diet. The company works hard to make sure that the right product is available at the right place at the right time at the right cost. The problem is that the company does not perform any market research to identify consumer behavior. Due to the lack of such market research the company fails to anticipate, adapt to or understand the changes in the market and in the behavior of customers. Therefore, the product provided has been consistently identical across the various periods of operation of the company regardless of market and consumer needs. Taking this into account, it is important to point out that when a different end product is needed (different in this instance means a variation in the format or alternative characteristics such all-purpose flour, pastry flour, cake flour etc.) the customer will need to purchase the product provided by Auras and then subject it to an additional process (at home or through another production entity) in order to reach the required final product. This leads to a situation in which the customer has to assume the role of manufacturer rather than directly obtaining their need from the company. Within the same market other companies exist such as Amar ben Amar which is conducting market researches but the Auras mills market share is untouchable due to the high quality of their products and their historical presence in the Algerian market.

Within the structure of this company the commercial department is responsible for all the transactions and customer interaction (receiving and organizing orders, scheduling delivery, handling feedback and claims).

2- Transportation: The enterprise depends on road transportation to deliver the orders, however the enterprise has only 10 old trucks which makes it very makes the timely and proper delivery hard to achieve for the enterprise thus negatively affecting customer satisfaction, moreover, the trucks are old and frequently break down, forcing the enterprise to rent trucks which results in additional costs both for the rental and the maintenance and repairs of the trucks.

3- Storage: The storage process starts with the receiving of purchases, the trucks unload their cargo at the receiving area, the cargo goes automatically into the pre-storage area through an automated chain with a capacity of 150 boxes, and this process takes the boxes to a big scale of 5 Quintal, when the Scale reaches the maximum weight it empties itself. This process takes 17 seconds. The last process of storage is the storage of the final 
product which is made automatically by machines and takes 45 seconds to fill a box of $100 \mathrm{~kg}$. These boxes are stored into a big hangar with two floors. Both floors have an area of $1218 \mathrm{~m}^{2}$.

4- Information and communication system: as per the enterprise description above, the enterprise uses the old communication system, and it mainly uses the letters and paperwork for most of its documentation and communication whether with the customers or between departments.

Supply chain in the enterprise:

We noticed from the above that the enterprise doesn't have a dedicated supply chain or logistics department; however we can see that some of the supply chain activities are directly implemented in some departments. This indicated that the various tasks to be achieved in the supply chain processes are partially implemented and spread across multiple departments (mostly divided between the production and commercial departments). Our approach will be to assess the restructuring of the company's organization to include a separate supply chain unit and the benefits that will result from this expenditure. Below is represented the new organizational chart after the creation of the supply chain unit as an independent department:

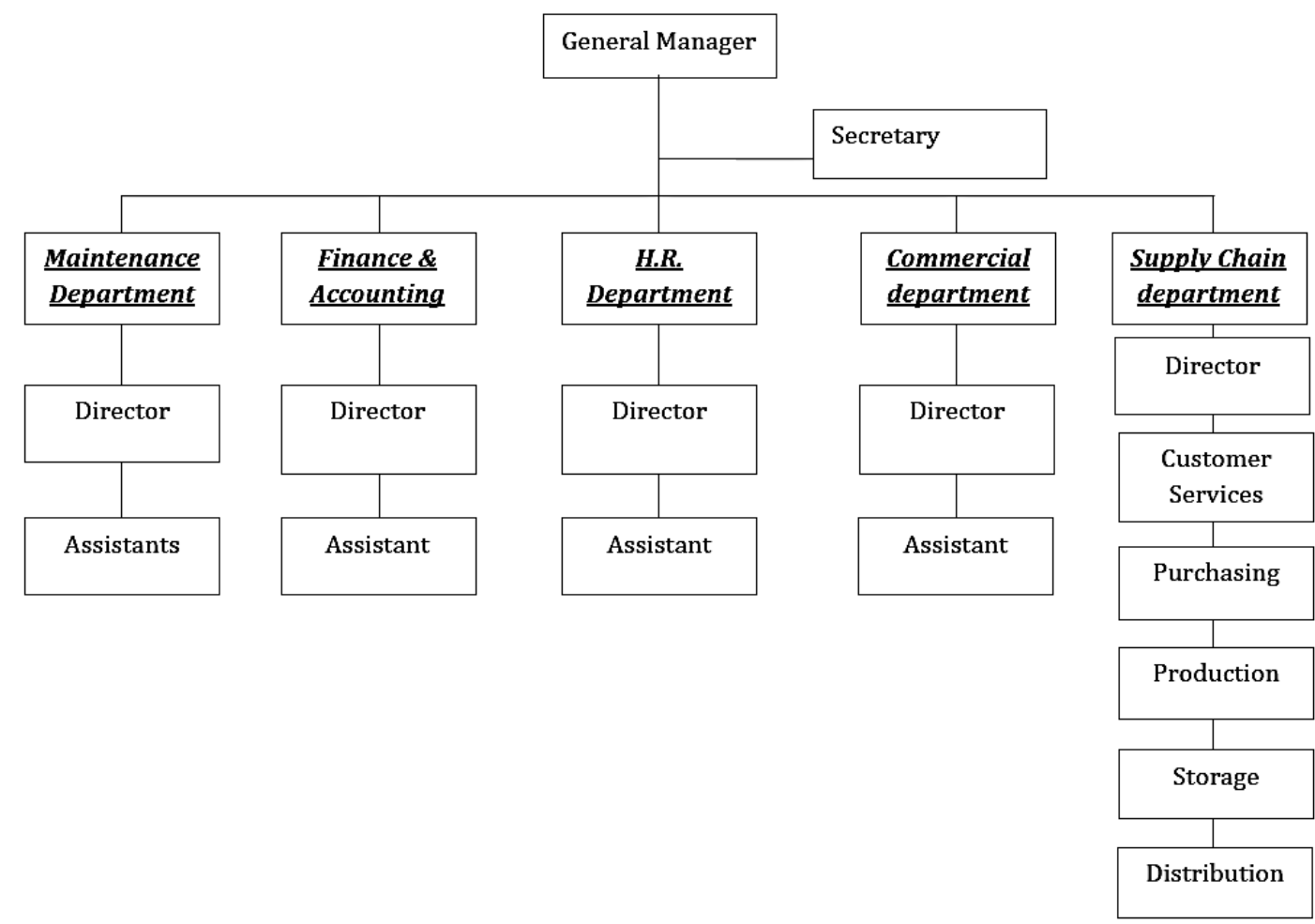

Figure IV: Proposed restructuring of the AURAS mills Source: Authors' own design.

We understand from figure IV above that the production and the commercial department switches tasks from being the unit in charge of dealing with customers' orders, requests and complaints to assume a marketing role to promote the company and its products while the newly established customer services departments will be tasked with handling the day to day orders and requests from customers. This allows the shift of the entire supply processes under one unit and the control of a single director that will 
have a better and faster hands-on approach to the entire set of activities related. In addition, this allows the commercial department to perform market analysis and market research that will determine the present and future needs of the market and the consumers and since the supply chain unit will be made of one single entity, it will be easier to adapt, plan and execute whatever shift in production or product the commercial team deems necessary. This concept will relate more closely to the current view of the relation between the various departments of a production company and its supply chain and will reduce the rate of cross-departmental task division within a single process. This will also positively affect the communication and coordination factors as the processes are limited to one unit that works in line to achieve a shared goal. Moreover, the creation of this new unit under the supervision of a dedicated director allows for a better quality management of the different tasks and provide the employees of the a direct person of reference to assist them and provide them with guidance, support and counsel in all matters related to the supply process.

\section{Enterprise competitive plan and the role of logistics.}

Our approach to the matter was cut short by the management of the company as during the interviews with the general manager and various directors an important issue was raised namely the lack of competitive vision from the part of the company and the lack of planning and strategy formulation which is mainly due to "the incompetency of the directors" as we were informed. This made the actual assessment of a practical change in the company impossible to implement and analyze.

\section{Conclusion}

Planning for the future of a company requires the management to establish long term objective that remain adaptable and flexible enough to accommodate any possible changes and variations in the market place, this is mainly relying on structuring and implementing a well-established supply chain process. The company observed in this paper has a traditional and outdated form of administration in which each department or director is mainly focused on achieving the task at hand as fast and as best as possible with little regard to the effect on other departments or on the possible benefit that arises from the proper combination of efforts of the various entities that form the company. This means that even though the company holds a good market share due to the high quality of the product, the delivery and the costs weren't controllable and subject to a large number or variables that affect the overall workflow of the company. In addition, the flow of information between the various departments within the enterprise is slow, outdated, error prone and inefficient. Had the company been willing to invest into a restructure that sets a dedicated department for the various supply chain processes, it would have possibly achieve an increase efficiency, cost control, time management, quality control and overall company competitiveness and brand name.

\section{References}

Balan, C. (2004). Logistica : functie integratoare si factor de competitivitate (2nd ed., pp. 26-27).

Enciu, G., and Nicolescu, A. (2007). Modern Logistics in Industrial Manufacturing. In 7th International Multidisciplinary Conference (221-228). Baia Mare: Scientific Bulletin Series C.

Gleissner, H., and Femerling, J. (2014). Logistics: Basics — Exercises — Case Studies (1st ed., p. 4). Springer Science \& Business Media. 
Haniefuddin, S., \& Khadar Baba, S. (2013). Essentials of Logistics and Supply Chain Management (2nd ed.). LPH International.

Jomini, A. (2008). The art of war. Restored Edition. Kingston, Ont.: Legacy Books Press. Online edition available at: http://www.legacybookspress.com/Books/Jomini.pdf [Accessed 12 Jan. 2018].

Kotler, P. (1995). Dirección De Marketing. (8th ed.). Prentice Hall.

Müller, W. (1811). The Elements of the science of war. London: Longman, Hurst, Rees,

PICBE $\mid 600$ and Orme.

Posea, C. (2005). Managementul logisticii firmei. Bucureşti: Editura Fundaţiei "România de Mâine."

Schileru, I. (2008). Acumulări şi dezvoltare in logistica comercială. Amfiteatru Economic $10(24), 41-58$.

Stock, J. and Lambert, D. (1993) Strategic Logistics Management, (3rd ed.) Irwin

V skills certified. (2018). International Logistics Tutorial | Concept and objectives of logistics. [online] Available

at: https://www.vskills.in/certification/tutorial/international-logistics/conceptand-objectives-of-logistics/ [Accessed 19 Jan. 2018]. 